Rozprawy Komisji Językowej ŁTN, t. LXVIII, 2020

ISSN 0076-0390; e-ISSN 2450-9310

https://doi.org/10.26485/RKJ/2020/68/9

Krystyna Szcześniak*

iD https://orcid.org/0000-0003-0672-8513

\title{
ZWIERZĘTA W WYBRANYCH TEKSTACH POLSKIEGO, ROSYJSKIEGO I BIALORUSKIEGO LEKAROWANIA
}

\author{
ANIMALS IN SELECTED POLISH, RUSSIAN AND BELARUSIAN TEXTS \\ OF LEKAROWANIE
}

Keywords: order, magic texts, animals, folk herbal medicine

Słowa kluczowe: zamowa, teksty magiczne, zwierzęta, ludowe lecznictwo ziołowe

\section{WPROWADZENIE}

W literaturze przedmiotu, jaką są zarówno zbiory zamów, jak i inne teksty (np. słownik Fischera z uzupełnieniami [Fi]), obok dominującej tematyki leczenia ludzi z rozmaitych chorób i przypadłości oraz skutków nieszczęśliwych zdarzeń, znaleźć można też przykłady na rytualne postępowanie w wypadku chorób zwierząt. Co ciekawe, zwierzęta występują w tych tekstach nie tylko jako leczony podmiot, ale także jako desygnaty używane w trakcie zamów. Spróbuję zatem odpowiedzieć na pytanie, jakie zwierzęta są podmiotem zamów, kiedy i z jakiego powodu takie słowa magiczne w ich intencji się wypowiada, a także kiedy w tekście zamowy pojawia się zwierzę jako desygnat i w jakim sposobie leczenia się to ujawnia.

* Uniwersytet Gdański, Wydział Filologiczny, Instytut Studiów Klasycznych i Slawistyki, Zakład Slawistyki i Studiów Bałkańskich, ul. Wita Stwosza 51, 80-312 Gdańsk, e-mail: krystyna.szczesniak@ug.edu.pl. 


\section{ZAMOWY BIALORUSKIE I ROSYJSKIE}

Materiał został zebrany z następujących prac białoruskich: Лечение словом. Молитвы и заговоры, 2004, Современное слово, Минск [LS]; Практика лечения молитвами и заговорами, 2003, Современное слово, Минск [PL]; Наталья Ивановна Степанова, 2005, 800 новых заговоров сибирской целительниць, РИПОЛ классик, Москва [St]; Наталья Ивановна Степанова, 2006, Гадания сибирской иелительницы, „РИПОЛ классик”т Москва [Ste]; Таццяна Васільеўна Валодзіна (укладанне, прадмова і паказальнікі), 2007, Народная медыцына. Рытуальна-магічная практыка, Беларуская навука, Мінск [Val]; Ганна Барташэвіч, 2000, Замовы. Уклад., сістэм тэкстаў, уступ. арт. і камент., Беларуская навука, Мінск [Z], a wzbogacony przez dane zaczerpnięte z publikacji Rośliny w wierzeniach i zwyczajach ludowych. Stownik Adama Fischera, autorstwa Moniki Kujawskiej, Łukasza Łuczaja, Joanny Sosnowskiej i Piotra Klepackiego, składającej się z dwóch części: uporządkowanej dokumentacji Fischera i haseł odnoszących się do roślin, „opracowanych współcześnie na podstawie materiałów zgromadzonych przez tego autora"1.

Co ciekawe, jedno ze źródeł białoruskich [Ste] zaleca przed rozpoczęciem ludowych praktyk leczenia ludzi wprawianie się w zamowach na zwierzętach, czego dowodzi lekcja pierwsza gadania, nosząca tytuł Первые опыты в учении на животныхx. Owe lekcje lekarowania polecają na początku zdobycie informacji, gdzie w okolicy znajduje się chory pies lub bydło domowe, a następnie poznanie jego imienia (jeśli takowe nosi) i koloru umaszczenia, a następnie, po wprowadzeniu tych danych do tekstu zamowy, pójście do domu, gdzie takie zwierzę choruje i wypowiedzenie tekstu odpowiedniego do sytuacji, choroby i zwierzęcia. Dopiero poduczywszy się na zwierzętach, można - zdaniem autorki owego opracowania - przystąpić do leczenia ludzi. Wspomniane źródło podaje kilka takich dolegliwości zwierzęcych, na których początkujący znachor ma się uczyć. Są to: чума рогатого скота [Ste, s. 96];

1 Znakomite wprowadzenie do tego słownika pokazuje, jak wielki trud uporządkowania materiału istniejącego do tej pory w maszynopisie [zob. Fi, s. 36] oraz realizacji zamysłu dołączenia do tego tekstu dokumentacji istniejącej do tej pory na fiszkach podjęli autorzy. Słownik w kształcie wydanym przez Polskie Towarzystwo Ludoznawcze w roku 2016 jest (po opracowaniu) bardzo bogatym zbiorem nie tylko ludowych nazw roślin, w zdecydowanej mierze spisanych wśród ludności polskiej, choć nie tylko - zanotowano w nim także ludowe nazwy wielu chorób ludzi i zwierząt oraz zwyczaje wykorzystujące rośliny do wróżb i wskazania najlepszego dlań zbioru i leczenia. Pojawiają się tu legendy związane z roślinami oraz wykorzystaniem ich w codziennym życiu ludności wiejskiej. Dla językoznawców ważne jest także to, że autorzy, będąc znanymi i doświadczonymi botanikami, podają przypisania roślin do nowych taksonomów, co umożliwia lingwistom i etnolingwistom porównywanie tych nazw z zapisanymi na przykład w zbiorach Elizy Orzeszkowej czy Zośki Wieras. 
заговор от чумы, от лошадиного кашля [Ste, s. 97]; от паршни у лошади [Ste, s. 98]; наговор на лошадей, чтобы у них не было ни болей, ни хворей [Ste, s. 98]. Potem następują odpowiednie zamowy na krowy (потеря жвачки [Ste, s. 99]; тяжелые роды у коров [Ste, s. 99]), a na końcu na świnie (nотеря аппетита [Ste, s. 99]; наговор от червей [Ste, s. 99]; чтоб свинья много ела; чтоб нарожденные поросята не подыхали; от порчи скота [Ste, s. 100]). Obok zamów tak zwanej białej magii, dotyczących leczenia zwierząt, autorka książki, której podtytuł brzmi: ja wam pomogę..., w dalszej kolejności podaje sposoby nakładania porczy na zwierzęta, dość zawile tłumacząc, dlaczego to czyni: Но вы должны знать, как напускают на скот болезни и порчи. [...] Для чего этому учить, скажете вы? Для того, чтобы знать все. Иначе и другое не будет у вас получаться. В учении все взаимносвязано. Врача учат и резать и зашивать [Ste, s. 100-101]. To prawda, dodaje autorka, że przyszłego lekarza uczą i krojenia, i zaszywania, ale przecież istota sprawy tkwi w tym, że on kroi po to, by leczyć, a nie po to, by świadomie szkodzić.

W dalszej części omawianej książki [Ste, s. 101-103] autorka podaje każdorazowo sposób na zadanie i sposoby zdjęcia porczy na bydło domowe. Wspomniany zbiór jest jedynym, do którego dotarłam, w którym podawane są sposoby zadawania złego. W dodatku zadawanie chorób zwierzętom domowym (po uprzednim wywiadzie terenowym) ma być w zamiarach autorki wprawką do podobnych zabiegów na ludziach. Ważne podkreślenia jest to, iż na pierwszym miejscu jest tu koń, potem bydło domowe, a na końcu świnie, zadawanie porczy jest zaś związane tylko z bydłem domowym (szczególnie chodzi tu o krowy i pozbawianie ich, w wyniku zamowy, mleka) ${ }^{2}$. Autorka wskazuje też sposoby zadawania, a także ich poszukiwania - zwraca uwagę na to, iż zadanie może nastąpić przez związanie szmatką dwóch blisko rosnących na pastwisku krzaczków - wierzchołkami. Czyje bydło potrąci te krzaczki, zachoruje - pomóc wówczas może tylko wbicie gwoździa we wrota ogrodzenia tego domu, w którym bydło zachorowało. Porczę można zadać też przez wycięcie nożem szczapki z ogrodzenia, a potem zabranie jej do swego domu - krowa traci wówczas mleko i chudnie. Jeśli podejrzewamy o takie właśnie zadanie, należy wziąć nawóz od chorej krowy i odrzuciwszy go na bok, wypowiedzieć odpowiednie słowa zamowy ${ }^{3}$. Inne sposoby zadawania pozbawiania krowy mleka to: na rzepę (rzodkiew, jabłko, rzadziej ziemniaki), na kłębek z sierści zwierzęcia, przewiązany czarną nitką.

2 W wielu źródłach słowiańskich (nie tylko wschodnich) wspomina się o tak zwanych wiedźmach mlecznych. Szerzej zob. Szcześniak, 2008.

3 Тому, кто попортил-говна, а моей корове - молока [Ste, s. 101]. 
W drugiej książce tej samej autorki [St] znajduje się cały rozdział poświęcony zapobieganiu porczy, odżegnywaniu zamów i uroków rzuconych na zwierzęta, który autorka zatytułowała Забота о животных [St, s. 295-315]. Znajdują się tam dwa teksty wypowiadane При рождении теленка ${ }^{4}$, jeden При покупке $\kappa о р о в b l^{5}$. Z tym ostatnim wiążą się trzy inne teksty, zapisane pod jednym tytułem: Чтобы скотина не тосковала по бывшим хозяевам ${ }^{6}$. Pierwszy z nich jest dłuższy, dwa pozostałe krótsze ${ }^{7}$. Wszystkie trzy są typowymi tekstami za-

4 Pierwszy z nich ma być wypowiadany trzy razy z rzędu bez żadnych świadków (Дедушка, соседушка, хозяин наш домовой, Прими теленка, как своего ребенка, Пои, корми, от худого глаза стереги [St, s. 295]), drugi zaś, odwołujący się do tego samego domowika, domowego, prosi go również o opiekę na nowo narodzonym cielątkiem (Хозяюшка мой домовой, Прими теленочка к нам домой, При достатке корми его сладко, Сам его не обижай и чужим На потеху не давай [St, s. 295]). Pojawia się tu przekonanie, że najlepiej to młode stworzenie upilnuje duch domowy, o którego dbano, którego zabierano ze sobą w czasie przeprowadzek i wierzono, że może on więcej niż człowiek.

5 Zanim wymówi się wróżebne słowa, należy zakupioną krowę zaprowadzić do chlewa, machnąć nad nią miotełką brzozową (Будь твое тело мясное гладко, Молоко бело и сладко, Сметана жирна и вкусна. А ты, батюшка - домовой, Заведи ее в хлев домой. День и ночь охраняй, Сглазить мою коровушку не давай. Ключ, замок, язык. Аминь [St, s. 295]). Tekst ten jest także przemową do domowika, domowego, aby dbał o krowę, nie pozwolił jej zauroczyć, ale pewną nowością w stosunku do powyższych zamów jest jego klasyczne zamknięcie i zaaminowanie.

6 Co ciekawe, terminem скотина obejmuje się tu zarówno krowy, jak i konie oraz другую скотину. Zamowę zaleca się wypowiadać w sytuacji, kiedy kupione zwierzę nie chce jeść ani pić, co może doprowadzić do jego padnięcia. W trakcie wypowiadania słów wróżebnych należy maczać w wodzie namówionej pęk gałązek (веник) i skrapiać ową wodą bydlęta. Zabieg ten spowoduje, że тоска перестанет сушить животину, и она скоро поправиться [St, s. 297]. Pierwsza zamowa (będąca z jednej strony przemową do bydlęcia i tłumaczeniem, że dawne gospodarstwo nie istnieje, a w nowym i siano jest bardziej miękkie, i pożywienie ciepłe, a z drugiej prośbą o uszanowanie nowej gospodyni i powracanie z pastwiska na noc do domu) ma już bardziej klasyczną budowę, zarówno jeśli chodzi o jej początek, jak i końcowe zamknięcie oraz zaaminowanie: Стану, благославясь, пойду, прекрестясь, В моем двору поле, иирокое раздолье. Хлеб тепльй, сено шелковое, Ешь, наслаждайся, пей, напивайся. У старого хозяина двор сгорел, Вода высохла, сено вымокло. О старом дворе, О прежнем житье не сомневайся, А мне, своей хозяйке, повелевайся. В любую теплую ночь домой из лесу возвращайся. В лесу и на выпасах не оставайся. Стой горой, дой рекой. Ныне и присно и во веки веков. Аминь [St, s. 297-298].

7 Drugi z nich należy wypowiadać w tym miejscu, gdzie stoi nowo kupione bydło: Bom тебе вода, вот тебе трава, У бывщей хозяйки трава переросла, вода утекла, А у меня шелковая трава, медовая вода. Пей, жуй, о бывшем дворе не тоскуй. Во имя Отиа и Сына и Святого Духа. Ньне и присно и во веки веков. Аминь [St, s. 298]. Jest to krótki, perswazyjny tekst, zakończony tradycyjnie, zgodnie z klasyczną budową, ale funkcję zamknięcia pełni tu przeżegnanie, po którym następuje zaaminowanie. Ostatni z tego cyklu tekst należy wypowiadać zaraz po przyprowadzeniu nowego bydlęcia do domu, po daniu mu chleba z solą i wody do popicia (Тоску запей, печаль зажуй. Будь во веки при мне, при Божьей рабе (имя). Слово мое лепко, дело мое, как репей, цепко. Во имя Отца и Сына и Святого Духа. Аминь [St, s. 298]). Bez charakterystycznego wstępu tekst ten zawiera tylko prośbę, 
żegnującymi pewne kłopoty z nowo zakupionymi zwierzętami. Przywoływany tu zbiór zamów Stiepanowej zawiera także teksty o tym, by na pastwisku nic złego się z bydlętami nie stało [zob. St, s. 315], żeby bydło nie uciekało (dwa teksty z St, s. 296, a także jeden na stronie 302: żeby bydto dobrze do domu wracało, żeby złodzieje omijali bydło oraz żeby krowa w trakcie dojenia nie poktadata sie [St, s. 299] i skuteczne w sytuacji Если корова быка не подпускает ${ }^{8}$ [St, s. 298, 314]).

Bydło było ważne w codziennym życiu, wystarczy przypomnieć, jak karano we wsi kobiety podejrzane o odbieranie mleka krowom (zob. np. Piotrusię z Dziurdziów Elizy Orzeszkowej), nie dziwią zatem również zamowy stosowane w wypadku, jeśli krowa mleko stracita [St, s. 311], a także by tegoż mleka nie straciła [St, s. 311]. W badanym źródle zapisano również słowa od zapalenia gruczołów sutkowych u krowy [St, s. 304] czy też od ciężkiego doju [St, s. 310] $\mathrm{i}$ tego, by krowa spokojnie stała przy dojeniu [St, s. 312-313], bez powodu nie ryczała [St, s. 312] i prośby, aby dawała dużo mleka [St, s. 311]. Wspomniane źródło podaje ponadto zamowy na pierwsze ocielenie krowy [St, s. 314], dobre ocielenie krowy [St, s. 299] czy też modlitewki wypowiadane $w$ wypadku trudnego cielenia się krowy [St, s. 311] oraz stowa po ocieleniu [St, s. 314] i teksty wypowiadane $w$ wypadku powtarzajacego się rodzenia się martwych cielat [St, s. 311]. Są odrębne zamowy od tego, by bydło nie padało [St, s. 303, 307-308] i nóg nie łamało [St, s. 305]. Inne teksty dotyczą zamawiania chudości bydlęcia [St, s. 309], krowiej grzybicy [St, s. 311], lub zawierają rady typu: Как заговорить коровий бзык [St, s. 308-309], zwany w innym miejscu понос [St, s. 308]. Są tam też ogólne обереги на скотину (w badanym źródle są dwa takie teksty ${ }^{9}$, odmawiające złym siłom dostępu do bydła domowego oraz jedna modlitewka dotycząca ochrony bydła [St, s. 315]). Zamawiane są też brodawki na

a następnie umocowanie, odwołujące się do mocy rzepu i końcowe zażegnanie sprawy wraz z zaaminowaniem.

8 Tu zaleca się podniesienie lewą ręką spodni męża do krowiego pyska i wypowiedzenie słów: Как мой муж (имя) на мне, Так и бык на тебе. Аминь [St, s. 298]. W tej zamowie stosowana jest zasada zastępowania tego samego (funkcjonującego w innym wymiarze) przez to samo, a z klasycznej budowy pozostało oprócz wezwania zaaminowanie.

9 Pierwszy z nich zaleca przyniesienie z rzeki wody, namówienie jej i opryskanie miejsca, gdzie żyje bydło, oraz wypowiedzenie słów: Пока эта вода сама назад в реку не уйдет, До той поры вражье слово мой скот не изведет. Ключ, замок, язык. Аминь [St, s. 315]. Tekst ten ma klasyczny wstęp dla tej odmiany zamów „dopóki..., dopóty...”. Wymienione w nim słowo, to oczywiście porcza - 'złe słowa'. Ma też klasyczne zamknięcie i zaaminowanie. Drugi tekst należy wypowiadać dziewięć razy, obchodząc gospodarstwo z pustym wiadrem: Помяни, Господи, Кротость иаря Давида и мать Елену, Так чтобы враги против меня Дел поганых не замышляли, Ртов своих не отворяли, Двора моего не урочили. Ключ, замок, язык. Аминь [St, s. 299]. 
wymionach u zwierzat [St, s. 306] i wrzody u koni [St, s. 307]. W tym ostatnim przypadku zalecane jest sporządzenie specjalnej maści z 200 gramów tłuszczu baraniego, 100 gramów dziegciu brzozowego, 50 gramów siarki sosnowej i 50 gramów wosku (np. ze świeczki), którą po roztopieniu i ostudzeniu do ciepłoty ciała należało nałożyć na szmatkę, która owiązywano rany, a następnie dopiero należało wypowiedzieć odpowiednie słowa.

We wspomnianym wyżej źródle występuje jeszcze zamowa От моли и насекомыхх в доме, która zaleca obchodzenie domu z zapalonym kadzidłem w czasie ubywającego księżyca. Sam tekst jest wezwaniem do zabrania z domu pcheł, żuków, świerszczy, karaluchów, moli i wszelakich dwuskrzydłych stworzeń, a kończy się klasycznym zaaminowaniem. Kilka zamów poświęcono psom: było to leczenie epilepsji, nieustannego skowytu (tu nakazano postępować tak jak w wypadku dziecka czymś przestraszonego, stałe płaczącego) dreszczy (u psów i kotów) i bezpodstawnego rzucania się psa na ludzi [St, s. 301-302]. Wszystkie wspomniane wyżej teksty dotyczą zabiegów mających uzdrowić zwierzęta z różnych dolegliwości lub też pozbyć się niechcianych pasożytów.

W innym źródle [LS, s. 82] znajduje się specjalna modlitewka zatytułowanа Молитва святому священномученику Власию, епископу Севастийскому, której wypowiadanie zaleca się 24 lutego (św. Własija męczennika), 31 sierpnia (św. Flory i Ławra) i 31 grudnia (św. Modesta Jerozolimskiego), a dotycząca lekarowania zwierząt domowych. Jest ona zapisana po modlitewce od febry i goracz$k i$, a przed tekstem od naglej i niespodziewanej śmierci. W samym tekście nie ma bezpośredniego wspomnienia o zwierzętach, jest to błagalna modlitwa o opiekę nad modlącymi się, wybaczenie im grzechów i zapewnienie życia w spokoju i pokoju duszy. Tekst ten znajduje się w dziale Leczenie słowem, w znaczeniu 'modlitwą w sprawie...'. W części Leczenie chorób i dolegliwości zagovorami znajduje się kolejny tekst: Снятие порчи с животных [LS, s. 115], który nie wymienia konkretnego zwierzęcia (w didaskaliach wspomina się tylko trzykrotne obchodzenie порченного животного z miseczką, w której znajduje się solona woda, i kropienie nią zwierzęcia w czasie wypowiadania słów odmowy ${ }^{10}$. Można też założyć, że ów tekst mógłby prawdopodobnie być wypowiedziany przy jakiejkolwiek porczy, zadanej nawet człowiekowi. Tylko jeden tekst w dokumentacji tego źródła dotyczy świń - jest to zamowa na to, by świnia dobrze przybierała na wadze [St, s. 304].

10 Режу и солю, и не даю. Не дам портить ни своему, ни чужсму, ни глупому.Ни по глупости, ни по жадности, ни из зависти, ни из корысти, ни по злости. Моя нога вперед встанет, рука опрокинет, и порча сгинет [LS, s. 115]. 
W dużym zbiorze Замовы. Уклад., сістэм тэкстаў, уступ. арт. і камент ${ }^{11}$ [Z] występuje nieco odmienny układ, a interesujące mnie teksty znajdziemy w częściach: Замовы, звязаныя з гаспдарчай дзейнасию чалавека; Замовы супраиь хвароб; Замовы, звязаныя з сямейным і грамадскім бытам. Jak wskazują same tytuły, mowa jest tu również o polowaniu, rybołówstwie itp., czyli pojawia się inny aspekt obecności samych zwierząt. Idzie tu bowiem nie tylko o zapobieżenie ich chorobom, ale również o to, by dzikie zwierzęta (też ryby, ptactwo) łatwiej dawały się łapać czy łowić. Zwykle nie chodzi tu o połowy na większą skalę niewodem czy innym typem sieci, ale о лойлю рыббы вудачкай $[\mathrm{Z}, 10]^{12}$, co po raz kolejny pokazuje, jak ważną rolę w codziennym bytowaniu odgrywała w tej części Słowiańszczyzny zamowa.

Podobnie jak w wyżej omówionych zbiorach zamów rosyjskich, największa liczba tekstów białoruskich odnoszących się do zwierząt, a zapisanych w tym zbiorze, poświęcona jest krowom, mniejsza koniom ${ }^{13}$ (czasem zwierzęta te wymieniane są w tym samym tekście obok krowy, świń, owiec, jeśli jest to zamowa, będąca odżegnaniem od złych zwierząt, wilków itp. [Z, 147]). Niekiedy pojawiają się tu owce i świnie (zamowa od wścieklizny krów, koni, owiec, świń, psów i kotów [Z, 432]; od choroby świń [Z, 290, 291]). Specyfiką wspomnianego zbioru jest to, że często dopiero bezpośrednio w tekście pojawia się gatunek zwierzęcia, gdy zamowa nosi tytuł ogólny, typu: Ад хваробы жывёль (krowa [Z, 192]); Худобу заціняюиь

11 Szerzej o tej pracy pisałam w książce Szcześniak, 2013 oraz w artykułach Szcześniak, 2007 i Szcześniak, 2008.

12 Numer podawany w tym wypadku przy skrócie nazwy źródła oznacza liczbę umieszczoną przy zamowie w tekście.

13 Konie w zamowach nie mają imion, a to, że chodzi o konkretne zwierzę, jest zaznaczane w tekście poprzez podanie maści i często określenia mój, ten oto: маіх каней $[Z, 156]$; сяму каню $[Z$, 205]; этага каня [Z, 207, 245]; із варанога каня шарсьиі [Z, 202]; этага каня варанога [Z, 253]; вараны конік [Z, 267]; конь мой вараной [Z, 289]; варанога каня [Z, 48]; рыжы, гнеды, вараны, мымасты, серы, сівы [Z, 218]; майму божаму конічку сівенькаму [Z, 195]; гнядога каня [Z, 248]; этага каня сівага [Z, 236]; гнедая шарсьиіна, мой конь [Z, 223]; гэтыя лошадзі, рыжыя [Z, 238]; рыжая, буланая (рознага колеру) [Z, 240]. Niekiedy występuje tylko określenia koń [Z, 224, 279, 280], konik [Z, 225]. 


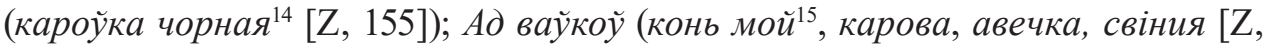
147]); Пры выгане скаціны (рагавой скат, авиุа, свінния [Z, 129]).

\section{ZAMOWY POLSKIE I LEKAROWANIE ZA POMOCĄ ROŚLIN}

We wspomnianym wcześniej słowniku Fischera [Fi], którego podstawą są rośliny, uwzględniono wiele leczonych nimi dolegliwości i chorób zwierzęcych. Często pojawiają się w tym leksykonie również słowa, mające wspomagać leczenie ziołami. Najczęściej materiał (podobnie jak w tekstach rosyjskich i białoruskich) dotyczy leczenia krów/bydła i koni, przy czym pojawiają się konkretne nazwy chorób. Niektóre z nich, co ciekawe, noszą te same nazwy, co u ludzi (przeziębienie, suchoty, robactwo), a inne (kurdziel, szczot) są określeniami odnoszącymi się tylko do konkretnych gatunków zwierząt bądź (tu podobnie jak w zamowach

$14 \mathrm{~W}$ tekstach zamów występujących w tym zbiorze bardzo często podkreślana jest informacja zamawiającego, że chodzi o jego bydło (moja krowa, moja chudoba [Z, 96-101, 109, 111, 113, 162, $164,184,251]$; мая каровачка $[\mathrm{Z}, 118]$; ta krowa $[\mathrm{Z}, 97,174]$; мая кароўка $[\mathrm{Z}, 122]$; мая иялухначка (масиь) $[\mathrm{Z}, 121]$; етая скаціна і жываціна $[\mathrm{Z}, 203]$; наша скаџінка $[\mathrm{Z}, 128]$; мая скацінка $[\mathrm{Z}$, 103, 108]; а етая скаціна [Z, 204]; гэтая скаціна [Z, 263]), о konkretną krowę. W tym ostatnim przypadku, co ciekawe, wyjątkowo rzadko występuje imię krowy (Рабка [Z, 273]; Жанка [Z, 277]; мая Мурка [Z, 125-126]; lub wezwanie: назваць карову [Z, 271]). O wiele częściej podawany jest kolor jej sierści, umaszczenia, czasem w postaci pustego miejsca i wezwania, by tu wstawić мacub [Z, 148, 158, 198]; масиь каровы [Z, 172]; a w większości wypadków - już ściśle określony: бурая скачіна $[\mathrm{Z}, 160]$; белая шарсьиіна $[\mathrm{Z}, 221]$; белая шарсиіна $[\mathrm{Z}, 252]$; гнедая шарсиіна $[\mathrm{Z}, 254]$; красна кароўка $[Z, 196] ;$ красна карова $[Z, 105]$; красная шарсціна $[Z, 162,212] ;$ красная кароўка $[\mathrm{Z}, 274]$; чорная шарсьиіна $[\mathrm{Z}, 149,164,166,168,239,283]$; карова мая чорная $[\mathrm{Z}, 106]$; кароўка чорная $[\mathrm{Z}, 155] ;$ чорна карова $[\mathrm{Z}, 130]$; чорная карова $[\mathrm{Z}, 186] ;$ рыжая скаціна $[\mathrm{Z}, 276]$; рыжая кароўка $[Z, 196] ;$ рыжая скаиінка $[\mathrm{Z}, 167,250]$; рыжая шарсиіна $[\mathrm{Z}, 170,199,213]$; рыжая шарьсиіна $[Z, 107,226,230] ;$ рыжа шэрсть $[Z, 247] ;$ раба карова $[Z, 235] ;$ раба кароўка [Z, 272]; рабая кароўка [Z, 94, 173, 194]; чырвоная [Z, 257]). W badanym zbiorze występują też w zamowach ciekawe określenia pstrej, niejednolitej maści krowy: скатіна двушэрстная [Z, 129, 244]; карова чорно-рабая [Z, 287]; a wyjątkowo dwie maści obok siebie: рыжая, чорная скаиінка [Z, 169]; скаціны бурыя, рабыя, красныя не мажэиь ўзяиі [Z, 131]. Są i takie teksty, w których wymieniona jest wprawdzie maść krowy, ale można ją zamienić na każdą inną barwę umaszczenia: кароўка чорьненькая ці якая [Z, 188]; раба (чорна і г. д.) [Z, 272]; сваю скацінку, рыжую (або іншая масцьь) шарьсцінку [Z, 272]; скаціна-жыьвиина, такую та шарсьцинье [Z, 222]; с естай скаціны, жывяцины, с такой та шарсьцины [Z, 222]. Niekiedy określenie bywa jeszcze bardziej rozbudowane: мая рыжа, лыса кароўка [Z, 201]. Ciekawa jest też pod tym względem zamowa 263, która zaczyna się słowami Выгаварваю [tak w zapisie - przyp. K.Sz.] з гэтай скаціны, чорна-рабой (можа быць рыжай, палавой, бурай і інш.)..., w której pojawia się jako druga jeszcze inna maść krowy, do tej pory niewymieniana w badanych tekstach.

15 Podobne postępowanie mamy w przypadku konia, na przykład w zamowie 85, zatytułowanej Ад уроку каню, gdzie występuje określenie памажы і майму божаму конічку сівенькаму [Z, 85], czy w innych zamowach: варанога каня шарсьиі [Z, 202]; сям кань [Z, 205]; етат кань [Z, 207]. 
wschodniosłowiańskich) sytuacji ważnych, na przykład ocielenia się krowy, wzdęcia zwierzęcia lub zaczarowania mleka. Oprócz zamów we wszystkich zapisach tego słownika zalecano podawanie konkretnych ziół, czasem wskazując również najlepszy czas ich zbioru i leczenia nimi, a także sposoby przyrządzania poszczególnych leków zielnych. Świeże piwonie, powiązane lipowym łykiem, mocowano na rogach krów lub do ogona (Bogusławice) w czasie pierwszego wygonu, zwykle mającego miejsce w okolicach dnia św. Jerzego.

O dolegliwości, na które cierpiały krowy, oskarżano często tak zwane wiedźmy mleczne. Dla ochrony przed ich czarami okadzano krowy suszoną piwonią, ale wskazywany zabieg należało przeprowadzać w nieszpory lub oktawę przed Zielonymi Świątkami (wtedy, jak wierzono, czarownice były najbardziej aktywne). Na Wołyniu (zapewne dla odsunięcia czarów wspomnianej wyżej wiedźmy mlecznej) polecano: rutę, boże drzewko z krzyżownikiem gotować w occie i lać w gęby bydtu, aby połykało tę polewkę, każdemu po pót kwarty, tymże pokropić oczy i czary $w$ bydlęciu ustępuja [Fi, s. 466-469].

Wiedźmy miały (jak wierzono) wpływać nie tylko na jakość i ilość mleka, ale też na stan zdrowia krów. Wiele zapisów źródłowych dotyczy postępowania w wypadku opuchlizny wymienia krowy, np. rozparzonym rozchodnikiem okładano zapuchnięte wymię krowy (czy to z powodu ukaszenia przez owada, czy wskutek czarów), kiedy zwierzę nie dawało się wydoić (Brenna). W Wielkopolsce, podejrzewając działanie czarów, mówiono o psuciu się mleka - wówczas: trzeba doić przez wianek z rozchodnika [Fi, s. 286]. W okolicach Dobrzynia podczas pomoru bydła, o który zwykle również oskarżano tak zwane złe siły, rozpalano ogień z dziewanny, bylicy, jałowca i macierzanki, i przepędzano przezeń stado [Fi, s. 141]. Powszechnie wierzono, że to pierwsze ziele, szczególnie zebrane w noc św. Jana, ma moc odpędzania złych mocy, dlatego palono je przy obrzędzie sobótki na odpędzenie (tak od ludzi, jak i zwierząt) czarownic i czarów (pow. Łomża). Dla wzmocnienia działania święcono dziewannę na Matkę Boską Zielną (Małopolska), chowając wiązankę za strzechą, po czym okadzano nią izby, aby uchronić się od złego, a bydło okurzano w celu uwolnienia go od choroby (szczególnie tej zadanej), a także w celu wpłynięcia na dojność krów, wydajność masła itd. (okolice Przeworska) [Fi, s. 138-139]. W tych samych celach w Krakowskiem okadzano krowy poświęconym kopytnikiem [Fi, s. 210]. Najbardziej drastyczny zwyczaj na pozbycie się oczarowania mleka zanotowano w Brennej, gdzie (jeśli uznano, że mleko jest zaczarowane), przecedzano je przez nowe płótno, które potem kładziono na biało kwitnący krzew, np. ostrężyny (Rubus fruticosus), przy czym zabieg ten wykonywano niekoniecznie podczas kwitnienia (ważna była świadomość, że kwitnie on na biało). Jeśli rzeczywiście w zepsuciu mleka miały swój udział wiedźmy mleczne, na płótnie miały ukazać się białe robaczki. Aby odczarować mleko, należało im połamać nóżki lub je zabić, a wtenczas ten, kto zaczarował mleko, 
złamie nogę lub umrze. Zabieg polecano wykonywać na nowiu przed wschodem słońca [Fi, s. 174].

Okresem, kiedy krowy były, jak wierzono, szczególnie narażone na działanie złych sił, był czas cielenia lub następujący bezpośrednio po nim. W źródłach zapisano wiele informacji mających chronić zwierzęta. I tak w czasie cielenia się dawano krowom w Królówce do picia wodę, w której wcześnie gotowano suszone zioła z bukietu poświęconego na Matkę Boską Zielną: dzwonek, lebiodkę, spis, kalina i macierzanka dodając do nich groch, kilka kłósek żyta, kilka pszenicy, parę listków z kapusty i parę gtówek maku (Królówka). Na Podhalu karmiono je wówczas parzonka z ziemniaków i kapusty [Fi, s. 327] lub marunką (wrotycz) [Fi, s. 490], albo też, jak w Dobczycach (aby się krowy dobrze miaty) podawano rutę [Fi, s. 466-469], niekiedy przypominając o wzięciu rośliny z wiązanki poświęconej 15 sierpnia (Przecław). W Zawoi dodawano to ziele do sieczki [Fi, s. 461-462].

Aby wzmocnić zwierzę po porodzie, w okolicach Bielin pojono je odwarem z ziół (w tym piwonii) święconych na Boże Ciało [Fi, s. 448], a w Krakowskiem dawano mu dziewannę (też inne zioła) [Fi, s. 141] lub pojono odwarem z rojownika (Bieliny). Uważano tam, że równie skuteczne będą zioła $\mathrm{z}$ wianeczka poświęconego w oktawę Bożego Ciała (przechowywano go na zewnętrznej stronie chaty), które gotowano i odcedzano, a potem wywarem pojono zwierzę [Fi, s. 463-464]. Pomocne w okresie dochodzenia do pełnego zdrowia bydlęcia miały też być zioła $\mathrm{z}$ bukietu poświęconego na Matkę Boską Zielną (Królówka), takie, jak: dzwonek, lebiodka, spis, kalina i macierzanka, groch, kilka któsek żyta, kilka pszenicy, parę listków z kapusty i parę główek maku. Równie skuteczny miał być też wywar z kocanki i innych ziół, wziętych z poświęconego wianka (nie podano tym razem, kiedy go święcono), zmieszanych z siemieniem i cebulą rozkrojoną na cztery części oraz ospą żytnią, który podawano krowie po ocieleniu [Fi, s. 391].

Niekiedy zabiegi lecznicze wzbogacano dodatkowymi czynnościami o charakterze magicznym. Na przykład w wypadku krów chorych na zut, czyli 'bóle wymienia', dawano zwierzętom do picia odwar z ziela, kreśląc przy tym wymię na krzyż pierścionkiem ślubnym lub samym zielem (Szczepanów). Z kolei liśćmi gliśnika nacierano zwierzęta (mające chorobę skóry) oraz wymiona krowy świeżo po jej ocieleniu. Korzeni tego ziela (ze względu na ich działanie wymiotne) używano, gdy dokuczały krowom wzdęcia (np. po zjedzeniu świeżej koniczyny) (Biała Góra) [Fi, s. 367-368]. Chore wymiona bydła nacierano również świeżym pędem sośniny (Radzyń), ale jednocześnie przestrzegano przed wypasem krów na trawie, na którą padają kwiaty sosny [Fi, s. 297-298], a zapuchnięte wymię krowy (czy to z powodu ukąszenia przez owada, czy wskutek czarów), kiedy zwierzę nie dawało się wydoić, okładano rozparzonym rozchodnikiem (Brenna).

Powszechnie wykorzystywano też w ludowym lecznictwie zwierząt len, a szczególnie jego siemię, rekomendując podawanie go krowom (po zmieszaniu z białkiem) 
jako dobry środek przeczyszczający (Królówka). Gotowane siemię dawano też bydłu na rozwolnienie, a w okolicach Leksandrowej pojono nim krowy na zasuszenie [Fi, s. 402-406].

Inną dolegliwością, która dokuczała zwierzętom, były zołzy, zwykle połączone z nabrzmieniem gruczołów mlecznych, które powszechnie okadzano rozchodnikiem [Fi, s. 461-462], a w Krakowskiem zwierzętom przy tej chorobie podawano ziele glistnika (jaskółczego ziela) rozgotowane w mleku, które powodowało szybsze dojrzewanie wrzodów, a potem ich pękanie [Fi, s. 368].

Bydlętom często zagrażały robaki, a na nie w Drohickiem puszczano sok żółtawy, pozyskiwany z marunki (wrotyczu) [Fi, s. 490]. Dużą rolę w wierzeniach ludowych miała w tym wypadku dziewanna, którą zamawiano robaki u bydła $w$ ranach. Informator podał, że $w$ tym celu idzie się po zachodzie słońca (czasem przed wschodem słońca) na pole, gdzie rośnie dziewanna, zgina się ja i przykłada kamieniem, mówiac: „Dopóty cię nie odchylę, az robaki nie wypadna z bydlęcia” (okolice Płocka). W Polsce południowo-wschodniej polecano w wypadku tej przypadłości pognieść w ręku dziewannę i trzykrotnie wypowiedzieć słowa: Jak tego (srokatego, biatego, czarnego itp.) bydlaka robak męczy, tak ja ciebie męczę. Z kolei informator z Ziemi Radomskiej podał nieco inny sposób zażegnania tej dolegliwości: Pójdziesz przed wschodem stońca tam gdzie dziewanna rośnie, wybierzesz jeden krzew i nie łamiąc czubka, pochylasz go do ziemi i przyciskasz kamieniem, mówiąc: męcy cię męcy, jak robak bydlaka dręcy. Informator dodaje, że zabieg należy powtórzyć przez kolejne trzy dni, a potem choroba ustaje, a wówczas wracasz do dziewanny i kamień odejmujesz, a ta uwolniona znów do góry wesoło się podnosi (okolice Radomia) [Fi, s. 141]. Robactwo, ale rozwijające się we wnętrzu, powodowało często zaburzenia w trawieniu, a wówczas w Krakowskiem polecano podawać bydlętom liście konopne razem z liśćmi tatarakowymi [Fi, s. 205] lub poić je (Leksandrowa) wywarem z marunki, skutecznym też na bliżej nieokreślone boleści i kłopoty z wypróżnianiem [Fi, s. 490]. W materiałach zgromadzonych przez Fischera zapisano też informację, że nasienie lnu zmieszane $\mathrm{z}$ białkiem działa na krowy przeczyszczająco (Królówka), a w Leksandrowej gotowane siemię dawano bydłu na rozwolnienie i do picia krowom na zasuszenie [Fi, s. 406].

Krowy mogły się przeziębić, a na tę dolegliwość podawano im (Bochnia) do picia gotowane liście konopne wraz z tatarakowymi [Fi, s. 205]. Z różnych powodów mogły też chwiać się im zęby, a wówczas polecano w Dobczycach ttuc marunkę z sola i nacierać krowom dziąsła [Fi, s. 490]. Na paskudnika, dolegliwość, której nazwy oficjalnej nie udało mi się znaleźć, tarto bydle marunka po bokach i po grzbiecie, a paskudnika (na oku) (Bieżanów, Brzyczyna) zasypywano pieprzem lub zrywano (Radziszów) [Fi, s. 490]. Przy suchotach u krów w Poznańskiem polecano podawanie do picia zaparzonych kwiatów kocanek [Fi, s. 391]. Inną chorobą tych zwierząt, na którą szukano leków ziołowych, był kurdziel, do leczenia którego polecano 
dziewięćsił. W Krakowskiem go zażegnuja tym osetkiem, ale żeby zażegnywanie było skuteczne, musi mieć osetek do tego użyty dziewięć wierzchołków, pałek. Jeśli bydlę dostało na języku szczot (krosta na spodniej stronie języka), wyszukuje się osetek o trzech lub pięciu wierzchotkach, patkach i nasiekuje się nim język bydlęciu choremu [Fi, s. 143]. Jeśli bydlęta się roiły, podawano im do picia rojownik [Fi, s. 463-464].

Bardzo cennym zwierzęciem w gospodarstwie był koń, któremu też dokuczać mogły różne dolegliwości. W wypadku bliżej nieokreślonej choroby, a także przy kłopotach z wypróżnianiem podawano koniom w Dorożowie wrotycz marunę $\mathrm{z}$ ugotowanym jęczmieniem [Fi, s. 490]. Kopytnik, który powinien zostać zebrany w wigilię św. Jana i ususzony, dawano na Podhalu koniom do lizania - jako środek przeciw robakom [Fi, s. 210]. Przepis wołyński z roku 1830 zalecał na końskie puchliny wzięcie mieszanki paździerzy i siemienia konopnego i wsypanie jej do piwa, a potem gotowanie do gęstości kaszy i okładanie nią puchliny [Fi, s. 205]. Picie odwaru kminku (pow. Zamość) miało być skuteczne na podźwignięcie się lub pottuczenie źrebnej kobyły [Fi, s. 193].

Kompatybilnym przekonaniem o rozróżnianiu wśród kołtunów u ludzi samca i samicy i stosowaniu w celu pozbycia się ich odpowiednich słów, w okolicach Bochni rozróżniano męską i żeńską formę kurdziela (wrzodu na języku, szczególnie u koni), a używając do leczenia ostu, nakazywano wykopać go łopatą, po czym wsadzić do góry korzeniem i przeżegnać się, wypowiadając trzykrotnie: Mój panie oset, żebyś ty do tego konia kastanowego posed, wygnat kurdziela i kurdzielice, samca $i$ samice, ze wszystkich żyt $i$ kości, aby został w zdrowości. Wspominałam wyżej, że na podobną dolegliwość u bydła w Krakowskiem polecano dziewięćsił, zażegnując tym osetkiem kurdziela, ale żeby zażegnywanie było skuteczne, musi mieć osetek do tego użyty dziewięć wierzchołków, pałek. Jeśli bydlę dostało na języku szczot (krosta na spodniej stronie języka), wyszukuje się osetek o trzech lub pięciu wierzchołkach, pałkach i nasiekuje się nim język bydlęciu choremu [Fi, s. 142-143].

Warto tu przypomnieć jeszcze o jednym zwyczaju, mającym na celu zapewnienie domowym zwierzętom dobrego zdrowia. Otóż w nie tak dawnej przeszłości na Boże Narodzenie powszechnie pieczono opłatki z rutą i podawano je żywiole jako lekarstwo (Brenna). W niektórych regionach były to opłatki o kolorze zielonym, roznoszone również przez osoby związane z Kościołem, z góry przeznaczone tylko dla zwierząt (gospodarz po wieczerzy szedł do obory i dawał je zwierzętom), a na Wielkanoc podawano bydłu rutę z chlebem [Fi, s. 461-462]. W okolicach Przecławia to samo ziele, poświęcone 15 sierpnia, dawano bydłu dla zdrowotności, a w Zawoi dodawano je do sieczki [Fi, s. 461-462].

Oprócz krów i koni Fischer wymienia różne sposoby na utrzymanie na przykład gołębi w gołębniku (poleca karmienie ich Cuminum cyminum) [Fi, s. 193] oraz sposoby na pozbycie się pypcia u kur (szlachta polska na Wołyniu leczyła go 
przez wkładanie nazbieranego podczas żniw kminku kurom do napoju, niekiedy jako lekarstwo dawano kurom ziarno pszenicy święconej, a pypeć ginie (Gaj)). Aby kury dobrze się niosły, w okolicach Pińczowa w Wigilię Bożego Narodzenia sypano im pszenicę [Fi, s. 455-460]. W dzień św. Szczepana rano zdejmowano z cebrzyka obręcz, kładziono ją na ziemi i sypano doń ziarna jęczmienia, a potem wpędzano tam kury w przekonaniu, że przez wprowadzenie ich do tego izolacyjnego koła magicznego zabezpiecza się je przed porwaniem jastrzębia lub krogulca [Fi, s. 176]. Gdy kury dostały pypcia, podawano im ziarno pszenicy święconej, a pypeć ginął (Gaj).

W wielu zapisach dotyczących ludowego lekarowania pojawiają się pszczoły. Dbano o nie szczególnie ze względu na wartość miodu, którego dostarczały. I tak na przykład melisy (poświęconej 15 sierpnia na święto Matki Boskiej Zielnej) używano do wabienia pszczół do ula po ich wyrojeniu (Warszawa). Zielem nacierano też ule, aby pszczoły dobrze się roiły (Kupców), polecając zakładanie jego plantacji przy ulach, gdyż pszczoły chętnie zbierały z niego miód. W Drohickiem smarowano melisą korytko łączące ule przy przeprowadzaniu pszczół do innego ula. Melisa, zerwana z ogródka przydomowego, pielęgnowanego przez dziewczęta w okolicy Brennej i włożona do ula na 24 godziny, zdecydowanie zwiększała ich szanse na zamążpójście. Jak wspomina źródło: Niektóre narwały rojownika $i$ włożyły do wejścia do ula, gdzie pszczoly wylatuja, zostawity go na dwadzieścia cztery godzin i potem wzięly i zaszyly do sukni. Wierzyły, że mając takie ziótko przy sobie, będzie koło nich cały rój chłopców, jako pszczót [Fi, s. 436].

\section{PODSUMOWANIE}

Podsumowując te rozważania, należy podkreślić, że szczególnie często i dokładnie (z rozróżnieniem chorób i dolegliwości, a także specyficznych sytuacji wymagających zamówienia, jak np. tęsknota za byłym właścicielem) w zamowach (w funkcji podmiotu, tego, o zdrowie którego wypowiadany jest tekst magiczny) i ludowych przepisach leczenia ziołami wymieniane są zwierzęta domowe: krowa ${ }^{16}$ i końn ${ }^{17}$,

\footnotetext{
16 Rosyjskim leksemem skot, jak wynika ze wspomnianych tekstów, obejmowane były również konie.

17 Stosunkowo nieliczną liczbę tekstów poświęconych koniom niektórzy badacze tłumaczą tym, że były to zwierzęta świadczące o bogactwie właściciela, a zatem stosunkowo rzadko występujące we wsi. Warto jednak zauważyć, że niektóre teksty są na tyle ogólne, że mogą odnosić się do różnych zwierząt, zwłaszcza że używane tam określenia: жьвёла, худоба, a nawet скаиіна nie są jednoznaczne. Niektóre zamowy z kolei mają być ochroną zwierząt i ludzi przed ukąszeniem żmij, węży, gadów [Z, 293-352, 354-358, 360-429] lub przed wścieklizną i wtedy nie są wymieniane konkretne gatunki zwierząt - są to tak zwane обереги.
} 
a w dalszej kolejności: owce, świnie i wyjątkowo ${ }^{18}$ inne stworzenia: psy, rzadziej koty (na nie zwykle przenoszono choroby). Duża liczba tekstów dotyczących bydła domowego wpisuje się przy tym w tradycję ludową pogranicza wschodniej i zachodniej Słowiańszczyzny, związaną z wiedźmami mlecznymi i zadawaniem porczy na utratę mleka lub zdecydowane pogorszenie jego jakości czy też szybkie chudnięcie zdrowej do tej pory krowy.

Co ciekawe, tylko w wypadku konia i krowy mamy zamowy mówiące o ulżeniu w cierpieniach, choć znajdziemy wśród nich także teksty wskazujące na samego człowieka: jeśli krowa będzie spokojnie stała, szybciej się ją wydoi, jeśli da więcej mleka, w domu będzie więcej jedzenia, jeśli się zacieli i dobrze ocieli, będzie mięso bądź nowa jałówka. W wypadku tekstów odnoszących się do świni pojawia się tylko dbałość o to, by zwierzę dobrze przybierało na wadze, a nieliczne teksty magiczne mają je chronić od wilków (może to świadczyć, że niegdyś zwierzęta te wypasano na pastwisku, a nie tylko trzymano w chlewie i tam karmiono).

Zwierzęta domowe określane są w tekstach wschodniej Słowiańszczyzny różnymi nazwami zbiorowymi, jak na przykład жывёла [Z, 207], жывяціна [Z, 203], худоба [Z, 137], скаиіна, рагавой скот (ostatnie sformułowanie występuje jednostkowo w Z, 129), a w polskich tekstach zamów lub tych pochodzących z pogranicza i odnoszących się do ludowego lekarowania ziołami pojawia się bydło, zwierzęta domowe, nierogacizna.

Ciekawą sprawą jest dość często podkreślanie w zamowach, że chodzi o konkretne zwierzę (tu odpowiednie zaimki określające), konkretnej maści (interesujące leksemy określające umaszczenie zwierząt), wyjątkowo rzadko o grupę zwierząt (w domostwie było bowiem kilka krów czy koni), natomiast w stosunku do owiec czy świń występują tylko określenia: moje, te oto. Podobnie jak w wypadku zamów obejmujących ludzi wymieniane są imiona (czasem właściciela zwierzęcia, czasem samego zwierzęcia). W dużym zbiorze zamów [Z] występują wprawdzie tylko dwa imiona krów (pisane wielką literą: Raba, Żanka), myślę jednak, że tak krowy, jak i konie najczęściej nazywano od barwy ich umaszczenia. Za tą tezą przemawia wyjątkowo ciekawy zbiór leksemów określających umaszczenia krów i koni. Być może w zamowach funkcję imienia własnego pełnią też zaimki określające i dzierżawcze oraz dodawana do nich barwa umaszczenia ${ }^{19}$. Warto dodać, że niejednokrotnie w badanych zbiorach zapisano informację o przenoszeniu różnych chorób z ludzi na zwierzęta (głównie na koty i psy, czasem na kury lub koguta, koniecznie czarnego).

$18 \mathrm{~W}$ zbiorze [Z] prawie w ogóle nie ma innych zwierząt poza krową, koniem, owcą i świnią (jako podmiotem zamawiania), rzadko kotem czy psem (przy zamawianiu wścieklizny [Z, 432]) i rybą, czy różnym robactwem (jako czymś, co albo powinno dać się złowić, albo czego należy się pozbyć).

19 Być może tak było tylko w środowisku chłopskim lub mogło to dotyczyć zwierząt hodowlanych. 
Jeśli chodzi o same zamowy, to ich budowa często różni się od klasycznej - rzadko są to teksty pełne, zwykle pomijany jest początek, a zostaje samo wezwanie i zaaminowanie, czasem (rzadko) poprzedzone umocowaniem, zamknięciem. Niekiedy badanym tekstom magicznym towarzyszą dodatkowe zabiegi, jak na przykład obchodzenie kilkakroć zwierzęcia z pustym wiadrem czy pokazywanie mu desygnatów wspominanych w tekście (spodnie męża). W kilku wypadkach pojawiają się zamiast klasycznych tekstów swoiste modlitewki $\mathrm{i}^{20}$ do poszczególnych świętych, wypowiadane w dzień ich imienin.

W większości zbadanych tekstów, których celem miało być zachowanie zwierzęcia $\mathrm{w}$ zdrowiu bądź jego uzdrowienie, uleczenie z jakiejś przypadłości (kurdziel, szczot, paskudnik, robaki, zmniejszenie wydajności mleka lub zepsucie jego jakości), można było odnaleźć tę samą wiarę (podobnie jak w tekstach związanych z ludźmi) w moc słowa - tak zadawanego, jak i strzegącego czy umniejszającego cierpienia zwierzęcia. Wiele z badanych tekstów (niezależnie od języka, w jakim je zapisano) wspomina o zwiększaniu mocy ziół poprzez zbieranie ich w odpowiednim czasie (często wigilia św. Jana, ale także nów lub konkretna kwadra Księżyca; przed wschodem słońca, gdy jeszcze jest rosa lub po jej zniknięciu) lub wcześniejszym ich poświęceniu (w cerkwi niezależnie od daty, choć czasem wspomina się o Kwietnej Niedzieli, a w kościołach katolickich na Niedzielę Palmową, w Boże Ciało lub w oktawę tego święta i 15 sierpnia - w dzień poświęcony Matce Boskiej Zielnej).

Zabiegom towarzyszyły zwykle dodatkowe czynności, jak na przykład przykładanie do wrzodów szmatki (czasem dodawano, że musi być lniana lub konopna) nasmarowanej maścią zrobioną z dziegciu brzozowego, siarki sosnowej i wosku lub podawanie zwierzętom specjalnie przyrządzonych odwarów albo naparów zielnych (w trakcie ich przyrządzania nakazywano często zmówienie odpowiedniej modlitewki, modlitwy maryjnej lub Ojcze Nasz), którymi potem je pojono bądź nacierano im boki. Na koniec warto podkreślić, że w różnych regionach używano do leczenia zwierząt odmiennych lub tych samych roślin, co być może wynikało z tego, że poszczególne gatunki były dostępne (lub nie) w najbliższej okolicy. Zabezpieczano się też, aby w porze, kiedy nie ma dostępu do świeżych roślin, wykorzystywać te zioła, które wcześniej poświęcono, ususzono i przechowywano w miejscach do tego przeznaczonych (na wschodzie były to obrazy święte, ikony, za które zatykano pachnące ziółka, a na zachodzie i pograniczu wnętrze chaty).

20 Ten termin był powszechnie znany na Nadniemeniu [zob. Grek-Pabisowa, Handke, Ostrówka, Zielińska, 1998]. 


\section{ROZWIĄZANIE SKRÓTÓW}

Fi - Kujawska Monika, ŁuCzaj Łukasz, Sosnowska Joanna, KLePaCKi Piotr, 2016, Rośliny w wierzeniach i zwyczajach ludowych. Stownik Adama Fischera, Polskie Towarzystwo Ludoznawcze, Wrocław.

LS - Лечение словом. Молитвы и заговоры, 2004, Современное слово, Минск./ Lecheniye slovom. Molitvy i zagovory, 2004, Sovremennoye slovo, Minsk.

PL - Практика лечения молитвами и заговорами, 2003, Современное слово, Минск./ Praktika lecheniya molitvami i zagovorami, 2003, Sovremennoye slovo, Minsk.

St - СтеПАнова Наталья Ивановна, 2005, 800 новых заговоров сибирской иелительниць, РИПОЛ классик, Москва./STEPANova Natalija Iwanowna, 2005, 800 novykh zagovorov sibirskoy tselitel'nitsy, RIPOL klassik, Moskva.

Ste - СтеПАнова Наталья Ивановна, 2006, Гадания сибирской иелительницы, РИПОЛ классик, Москва./StерAnova Natalija Iwanowna, 2006, Gadaniya sibirskoy tselitel'nitsy, RIPOL klassik, Moskva.

Val - ВАлодзіна Таццяна Васільеўна (укладанне, прадмова і паказальнікі), 2007, Народная медыцына. Рытуальна-магічная практыка, Беларуская навука. Мінск./VALodzina Tacciana Vasiljeuna (ukladannye, pradmova i pakazal'niki), 2007, Narodnaya myedytsyna. Rytual'na-mahichnaya praktyka, Byelaruskaya navuka, Minsk.

$\mathrm{Z}$ - Барташэвіч Ганна, 2000, Замовы. Уклад., сістэм тэкстай, уступ. арт. $i$ камент., Беларуская навука, Мінск./BarTASHeVich Hanna, 2000, Zamovy. Uklad., sistem tekstaw, ustup. art. i kamyent., Byelaruskaya navuka, Minsk.

\section{BIBLIOGRAFIA}

Grek-Pabisowa Iryda, Handke Kwiryna, Ostrówka Małgorzata, ZielińsKa Anna, 1998, Bohatyrowicze sto lat później, Slawistyczny Ośrodek Wydawniczy, Warszawa.

SzCZEŚNIAK Krystyna, 2007, Świat roślinny zapisany we wschodniosłowiańskich zamowach leczniczych, [w:] C. Мусіенка, I. Крэнь (рэд.), Шлях да ўзаемнасиі. Mатэрыялы XIV міжнароднай навуковай канферэниыі, ГРДУ імя Я. Купалы, Гродна, s. 136-149./S. Musijenka, I. Kreń, Szliach ku vzajemnasci. Materjaly XIV miżnarodnaj navukovaj kanfierencyi, GRDU imia J. Kupaly, Grodna, s. 136-149. SzCZeŚniaK Krystyna, 2008, Od przestrachu-zamowa, [w:] A. Kątny (red.), Kontakty językowe i kulturowe w Europie. Sprach- und Kulturkontakte in Europa, Wydawnictwo Uniwersytetu Gdańskiego, Gdańsk, s. 67-84.

SzCZeŚNIAK Krystyna, 2013, Świat roślin światem ludzi na pograniczu wschodniej i zachodniej Słowiańszczyzny, Wydawnictwo Uniwersytetu Gdańskiego, Gdańsk. 


\section{Krystyna Szcześniak}

\section{ZWIERZETA W WYBRANYCH TEKSTACH POLSKIEGO, ROSYJSKIEGO I BIAŁORUSKIEGO LEKAROWANIA}

\section{Streszczenie}

Artykuł dotyczy obecności zwierząt w ludowych tekstach magicznych, ich leczenia lub miejsca w społeczeństwie. Autorka stwierdziła, że - niezależnie od języka zamowy czy tekstu leczniczego - wiele z nich wymienia przy leczeniu rośliny (też wymaga ich użycia). Często były one wcześniej zbierane o konkretnej porze, święcone w czasie różnych świąt religijnych (najczęściej 15 sierpnia), a następnie suszone i przechowywane w wyznaczonych do tego miejscach. Używano ich w razie choroby ludzi, a także zwierząt domowych (najczęściej krów, koni, rzadziej świń, owiec czy kóz, a wyjątkowo kur). Na inne zwierzęta (pies, kot, kury) przenoszono choroby ludzi. W przekonaniu ludzi rośliny były również pomocne w wypadku chorób zesłanych przez złe siły, czarownice i wiedźmy.

\section{ANIMALS IN SELECTED POLISH, RUSSIAN AND BELARUSIAN TEXTS OF LEKAROWANIE}

Summary

The article concerns the presence of animals in folk magical texts, their treatment and place in society. The author states that regardless of the language of zamowa or medical text, many of them mention plants when treating. Many of them also require their use. The plants themselves were often collected at a specific time, blessed during various religious holidays (usually on August 15), and dried and stored in designated places. They very used in the event of illness of people, as well as domestic animals (most often cows, horses, less often pigs, sheep or goats, and exceptionally chickens). People believed that plants were also helpful in diseases caused by evil forces, witches and milk witches. 
